\title{
Gait velocity exhibits more than $50 \%$ diurnal variation in Rheumatoid Arthritis: the divign study
}

\author{
Michael Backhouse ${ }^{1 *}$, David Pickles², Hannah Mathieson ${ }^{1}$, Lucy Edgson ${ }^{1}$, Paul Emery ${ }^{1}$, Howard Bird ${ }^{1}$, \\ Philip Helliwell ${ }^{1}$, Anthony Redmond ${ }^{1}$ \\ From Society of Chiropodists and Podiatrists Annual Conference 2010 \\ Bournemouth, UK. 21-23 October 2010
}

\section{Introduction}

Gait velocity (GV) is a frequently used outcome measure in studies of the lower limb in RA as it is reliable \& correlates with disease impact. Despite recent knowledge of marked circadian variation in inflammatory cytokine levels \& upper limb function, little is known about within-day variation of gait in RA.

\section{Objectives}

Describe patterns of diurnal variation of gait velocity in patients with RA

\section{Methods}

Inpatients with RA walked at self-selected speed along an $8 \mathrm{~m}$ GAITRite instrumented walkway (CIR Systems Inc, USA) 5 times during a single day; waking $(0 \mathrm{hr}),+1$ hr, $+3 \mathrm{hrs},+6, \&+12 \mathrm{hrs}$. Walking aids were allowed as required.

\section{Results}

Data were collected on 31 pts with RA (11 M, 20 F) median age of 67 (range 35 to 87), disease duration $10.5 y$ (range 1 to 50$)$, mean BMI $25.9(\mathrm{std}+/-5.5)$.
Median DAS28 5.39 (IQR 2.11) median HAQ 2.25 (IQR 0.79 ). The largest difference in GV between time points was the increase from $0 \mathrm{hr}$ to $1 \mathrm{hr}(20.4 \% 95 \% \mathrm{CI} 9.7$ to $31.2) \& 1 \mathrm{hr}$ to $3 \mathrm{hrs}(10.2 \% 95 \% \mathrm{CI} 2.0$ to 18.4$)$. Between $+3 \&+6$ was less $(6 \% 95 \%$ CI -1.5 to 13.4$)$ with a greater difference between 6 \& 12 hrs $(9.3 \% 95 \%$ CI 1.3 to 17.3) (Table 1).

\section{Conclusion}

Patients with RA showed systematic diurnal variation in GV with a sharp increase in the first hour after waking and continued improvement throughout the day. Although the effect of morning stiffness is well recognised, this is the first time that its effect on gait has been quantified. These data have important implications for the interpretation of gait analysis and other measures of functional capacity: Repeat measures should be made at a similar time of day to exclude the effects of diurnal variation.

\section{Author details}

'University of Leeds, Leeds, UK. ${ }^{2}$ Leeds Teaching Hospitals NHS Trust, Leeds, UK.

\section{Table 1}

\begin{tabular}{llllll}
\hline & $\mathbf{0 h r}$ & $\mathbf{+ 1 h r s}$ & $\mathbf{+ 3 h r s}$ & +6hrs & +12hrs \\
\hline Mean GV (cm/sec) & $37.6(+/-24.9)$ & $43.8(+/-28.7)$ & $45.5(+/-26.9)$ & $48.1(+/-29.0)$ & $53.0(+/-32.2)$ \\
$\boldsymbol{\Delta}$ from 0 hr $(95 \% \mathrm{Cl})$ & & $20.4 \%(9.7$ to 31.2$)$ & $32.9 \%(16.6$ to 49.3$)$ & $37.8 \%(21.6$ to 54.1$)$ & $54.1 \%(25.3$ to 82.9$)$ \\
\hline
\end{tabular}

'University of Leeds, Leeds, UK

Full list of author information is available at the end of the article 
$50 \%$ diurnal variation in Rheumatoid Arthritis: the divign study. Journal of Foot and Ankle Research 2010 3(Suppl 1):P1.

Submit your next manuscript to BioMed Central and take full advantage of:

- Convenient online submission

- Thorough peer review

- No space constraints or color figure charges

- Immediate publication on acceptance

- Inclusion in PubMed, CAS, Scopus and Google Scholar

- Research which is freely available for redistribution

Submit your manuscript at www.biomedcentral.com/submit
C Biomed Central 